\title{
Improving the quality of philosophical writing: Experimentation on the first philosophical compositions of 12 and 13-year old pupils
}

\author{
Pré-Print
}

\author{
Emmanuèle Auriac-Slusarczyka, Hélène Maire $a, b$, Cathy Thebaulta \\ and Bernard Slusarczyka 5 \\ aACTé Laboratory (EA 4281), University of Clermont Auvergne, Clermont-Ferrand, France; ‘Psychology and \\ Neurosciences Laboratory (EA 7489), University of Lorraine, Nancy, France \\ ARTICLE HISTORY \\ Received 11 August 2018 \\ Accepted 22 October 2018 \\ KEYWORDS \\ Philosophical writing; quality \\ of writing; creativity; logic; \\ school
}

Abtsract: Philosophy for Children (P4C) is a collective (teaching) practice which has been shown to foster language abilities, logic and creativity in children. While these benefits obtained with the $\mathrm{P} 4 \mathrm{C}$ oral practice have been well documented, philosophical writing received little attention. The aim of this paper is to examine which conditions better promote the quality of philosophical writing. Six writing conditions were proposed to a total of 317 students between the age of 12 and 13 from various socioeconomic backgrounds. These conditions varied according to the media (image, dialogue, key words) and the topic (dichotomous, not dichotomous). The quality of philosophical writing was assessed according to several indicators reflecting linguistic, logical and creative performances. Results show that the quality of philosophical writing depended on the media and the topic which were proposed, indicating different types of language planning across conditions. Interestingly, the image (vs. dialogue or key words) encouraged creativity detected by a more frequent use of metaphors, while distinctions between concepts were more frequently made from a dichotomous (vs. not dichotomous) topic. The functions of metaphors and examples are discussed in parallel with gender and school effects obtained in this study. 
Key-words: philosophical writing; quality of writing; creativity; logic; school

\section{Acknowledgments}

The authors thank Julie Pironom, research engineer at Laboratoire ACTé, for her advice on certain statistical analyses. This study is part of the COPHILEC (2016-2019) research project, funded under the experimental creation phase in the greater Auvergne-Rhône-Alpes region of Instituts Carnot de I'Education, aimed to bring together educational projects (schools) and research projects (humanities and social sciences laboratories).

\section{Disclosure statement}

No potential conflict of interest was reported by the authors.

\section{Introduction}

For over 30 years and following in the footsteps of transatlantic pioneers (Lipman, Sharp, \& Oscanyan, 1980), the practice of Philosophy for Children (P4C) has developed considerably in elementary school grades. This growth has allowed pupils to discover philosophy in kindergarten, the primary grades and more recently in middle school, with growing interest and impetus of educational research for these practices (Auriac-Slusarczyk \& Colletta, 2015; Daniel, 1992/1997; Pallascio \& Lafortune, 2002; Saint-Dizier de Almeida, Colletta, Auriac-Slusarczyk, Specogna, \& Fiema, 2015; Tozzi, 2007). In this type of exclusively oral P4C practice, pupils are invited to discuss freely universal, social, ethical, etc. subjects. These types of topics have the advantage of allowing children to explore them without any previous disciplinary knowledge (Auriac-Peyronnet \& Daniel, 2009; Rispail, 2007), since it prioritises the intellectual and collective process formed of alternatives, taking stands, contradictions and differing viewpoints that are shared and changed through verbal exchanges $^{1}$ (Daniel, 2003, 2005; Daniel \& Pallascio, 1997; Fiema \& Auriac-Slusarczyk, 2013).

After surveying the benefits of these oral philosophical practices, this study aims to explore the educational conditions likely to engage students in producing philosophical

\footnotetext{
${ }^{1}$ For a realistic view of $\mathrm{P} 4 \mathrm{C}$ content and form, visit the platform: http://philosophemes.univ-bpclermont.fr.
} 
writings. How should the exercise of written philosophical skills be envisaged? Which topics and which media should be preferred in order to obtain high-quality texts? First, we will examine the academic benefits of practicing philosophy at school. Then, we will present the conditions for a successful transition to writing from the viewpoint of cognitive psychology, before selecting indicators to determine quality philosophical composition in light of the literature on the subject. Ours is an exploratory approach.

\section{The benefits of oral philosophical practice from primary grades to middle school}

Very generally, an overall advance of intellectual maturity of 27 months was originally revealed in students philosophising orally (the so-called solid cord effect; Lipman, 1991/1995; Mortier, 2005), with children progressing strongly in their area of potential development, according to Vygotsky (Auriac-Peyronnet \& Daniel, 2005; Vygotsky, 1962). Subsequently, the benefits of school programmes introducing philosophy orally in an innovative way in the classroom have been demonstrated in various areas: both personal/interpersonal and cognitive/academic (Garcia-Moriyon, Rebollo \& Colom, 2005; Gregory, Hayes, \& Murris, 2017; Millett \& Tapper, 2012; Trickey \& Topping, 2004).

In personal and interpersonal areas, it has been shown that regular philosophical practice among pupils promotes social skills and understanding emotions (Giménez-Dasí, Quintanilla, \& Daniel, 2013), self-regulation (Heron \& Cassidy, 2018), anxiety reduction (Trickey \& Topping, 2006), self-reported communication and resilience abilities (Siddiqui, Gorard, \& See, 2017), although it may also increase emotional instability (Colom, Moriyón, Magro, \& Morilla, 2014). Furthermore, this practice appears to encourage self-esteem as a learner (Lafortune, Mongeau, Daniel, \& Pallascio, 2000), general self-confidence (Trickey \& Topping, 2006), emotional experience ability (Leleux, 2005; Millett \& Tapper, 2012), 
prosocial behaviour (Colom et al., 2014), as well as open-mindedness, an orientation toward otherness and a tendency to reconcile points of view (Çokluk-Bökeoğlu, 2008).

In cognitive and academic areas, oral philosophical practice encourages commitment in the classroom (Yusoff, 2018), language performance (Jenkins \& Lyle, 2010), understanding of texts among allophone students (Tian \& Liao, 2016) and application of argumentation abilities (Gasparatou \& Kampeza, 2012; Leleux, 2005; Millett \& Tapper, 2012). It encourages students to justify their point of view more and increases their oral participation in class (Topping \& Trickey, 2007b, 2014). Finally, it promotes reasoning skills (Leleux, 2005; Millett \& Tapper, 2012; Walker, Wartenberg, \& Winner, 2013), including verbal reasoning (Säre, Luik, \& Tulviste, 2016), improves performance on cognitive skills testing measuring verbal, non-verbal, quantitative and intelligence aspects (Topping \& Trickey, 2007a) and increases IQ by an average of seven points (Colom et al., 2014; GarciaMoriyon et al., 2005).

These works generally concern especially primary pupils and highlight the significant and varied benefits of P4C, particularly in socially disadvantaged children (Gorard, Siddiqui, \& See, 2017; Siddiqui et al., 2017).

\section{The conditions for a transition to philosophical composition}

While the practice of P4C is intrinsically oral and collective, the associated beneficial effects can also be observed in written production. A few works have highlighted the effects in primary grades using writing collected in ordinary classroom or experimental conditions (Auriac-Slusarczyk, Thebault, Slusarczyk, Daniel, \& Pironom, 2018; Maire, AuriacSlusarczyk, Slusarsczyk, Daniel, \& Thebault, 2018). For example, the idea generation process among students is positively impacted by philosophical practice in both argumentative quantity and quality (Auriac, 2007; Auriac-Peyronnet \& Daniel, 2005). However, the scarcity 
of studies in the field of written production goes hand in hand with the desire of the founder Lipman to consider philosophy for children as an intrinsically and collective oral activity, based on dialogue in a research community formed by the group of students thinking and talking together (Topping \& Trickey, 2014). Moreover, the more prosaic difficulty of delineating what philosophical composition might consist of, since it is not taught in the French system before the age of 17 years (final year of secondary school), closely follows the historic need to define oral philosophy (Auguet, 2003). Although philosophical writing cannot be reduced to a single, widely studied, argumentative genus (Golder, 1996; Golder \& Favart, 2003), it benefits from being characterized as a textual genre (Dolz \& Schneuwly, 1998) or as a type of speech (Bronckart, Bath, Schneuwly, Davaud, \& Pasquier, 1985) as these genres and types have been studied for a long time in the field of education.

Due to the lack of benchmarks in philosophy, we proposed a minimal definition of philosophical composition in our previous work (Auriac-Slusarczyk et al., 2018; Maire et al., 2018), that might include the writings of young students whose level of schooling is well below the possible exercise of composition writing (see Choulet, Folsheid, \& Wunenburger, 1992). In this minimalist perspective, philosophical writing lies somewhere at the crossroads between dissertation (linguistic and logical aspects) and invention (creative aspects). It requires the logical organisation and/or orientation (selection, planning, reasoning) of ideas when creating the text. The organisation of personal knowledge would be based on a predefined topic (e.g.: What is friendship?). To be philosophical, the text would examine the topic from different angles, compare them, identify them and explore them via an adventurous intellectual process already described orally (Beausoleil \& Daniel, 1991): based on this organisation, by presenting postulates (shared knowledge doxa), original and/or shared hypotheses and examples, certain ideas would be explored further to achieve the rank of concepts (e,g.: “emotions”, “time”). 
A more impressionistic share (feelings, perceptions, digressions) belonging to natural thought (Grize, 1990) would apply to the knowledge activated in an argumentative manner. A number of concepts (key ideas) would then be developed, in parallel or simultaneously as in oral exercises (Fiema, 2015; Fiema \& Auriac, 2013), and would activate more or less conceptual distinctions tracing main lines, reflections and doubts, and putting the comments into perspective. Mental imagery and reasoning by analogy should probably be considered at this level (Hofstadter \& Sander, 2013). Furthermore, because it is personal, philosophical writing is a highly creative activity.

Despite universal themes recurring throughout history, philosophical writing remains contextualized, belonging to a certain time ${ }^{2}$. Moreover, philosophical writing has no reader; one writes for oneself, as for autobiographical compositions (Montaigne, Rousseau), or to influence society, as is the case for pamphlets or press articles. Combining theme and thesis, philosophical writing remains in principal dialogic (i.e., crossed by contradictions, differences and alternatives) summoning the continuation of reflections by/with others (Bakhtine, 1978). Certain philosophers have offered a comprehensive definition: "a philosophical text develops proposals, according to a certain order of succession of sentences with a certain style (compact or diluted, elliptical or verbose) and in a certain atmosphere (a polemic tone or with a degree of serenity), a set of ideas, hypotheses, opinions and judgments that can all be more or less well connected, illustrated, presented and argued" (Choulet et al., 1992, p.347). However, in psychology, there is currently no macro-structural model (Sanders \& Schilperoord, 2006) for the philosophical text.

\section{Studying the quality of writing in philosophical writings based on various indicators}

\footnotetext{
${ }^{2}$ For example, the side effects of medications for the post-modern world versus poisoning for the ancient world (Aristotle) will illustrate the path of thinking engaged in an inquiry that remains universal: what does man seek when he seeks treatment? Can medicine be practised in an ethical manner?
} 
In cognitive psychology, quality of writing is traditionally studied based on different indicators revealing the cognitive processes underlying the writing activity (Alamargot \& Chanquoy, 2001; Fayol, 1997; Rijlaarsdam, Van den Berg, \& Couzijn, 2005; Torrance \& Jeffery, 1999). Although widely shared, these indicators nevertheless continue to be disputed in terms of their relevance for the developmental field (Gaonach \& Fijalkov, 1998) and should be regularly reassessed on a multidisciplinary basis (Gunnarson-Largy \& Auriac-Slusarczyk, 2013) and according to the contexts of study (McArthur, Graham, \& Fitzgerald, 2006). However, a consensus has been reached establishing that the quality of the writing of a text is generally revealed via certain linguistic characteristics. In the case of philosophical texts, since oral practice is designed to stimulate logical and creative thinking in concert (Lipman et al., 1980, pp. 79-81), the quality of writing can also be evaluated based on logical (critical) and creative components. Below, we identify indicators characterising the linguistic, logical and creative components used to assess the writing quality of a philosophical text.

In terms of psycholinguistic processes, the degree of developmental progress is traditionally measured by comparing the textual planning strategies of novices with those of experts (Scardamalia \& Bereiter, 1991). It is in middle school that planning using preparatory writing (drafts; Auriac \& Favart, 2007; Docquet-Lacoste, 2009; Fenoglio, \& BoucheronPétillon, 2002; Piolat, 2010; Piolat \& Barbier, 2007) becomes effective (Pouit \& Golder, 1996, 1997): students move beyond the so-called step-by-step local planning used by novices toward more expert comprehensive planning (Fayol, 1997; Garcia-Debanc \& Fayol, 2002; Hayes \& Flower, 1980; Slusarczyk, 2010), thanks to an increase in their working memory resources (Torrance \& Jeffery, 1999). Inherited from developmental studies on the story genre, referential anchoring (explicit link between the context and the text) as well as the ability to explicitly open and close a text (introduction, conclusion) are traditionally considered marks of good writing (Fayol, 1997, 2017). In addition, the length of the text, 
measured in the number of proposals or words, is an indicator showing an increasing degree of control and thus quality of writing (Alamargot \& Chanquoy, 2001; Auriac \& Favart, 2007). Finally, the enumeration of discursive markers, inherited more from work on argumentative texts (Coirier, Favart, \& Chanquoy, 2002) reflects the economy linked to both local and global planning. In our pedagogical perspective (Alkhatib, 2012), we aim for quality in terms of textual coherence and cohesion, thereby distinguishing markers of local connectivity (syntactic connectors) of the marks of the text's general organisation (discursive markers) (Coirier et al., 2002).

Concerning the logical component, the semantic content of writing is conventionally measured by counting the number of ideas, or the ratio of the number of ideas to the number of the textual proposals (Auriac \& Favart, 2007; Torrance, Thomas, \& Robinson, 1996). When applied to philosophical writing, the number of concepts addressed in the text (key ideas) can be counted within the textual planning process, in both the produced text and the draft. Similarly, the manner in which the writer makes distinctions between these concepts and does or does not build on them to structure the text can be compared to the mode of planning and reflect the text's logical quality (Auriac-Slusarczyk et al., 2018; Maire et al., 2018). For example, in our study, some students (writing on the topic of dreams) made local distinctions (dream/nightmare: "Dreams are gentle and nice, but nightmares are strong and sometimes violent"). Similarly, some students (writing on the topic of the difference between humans and animals) made a distinction that was planned step by step: "Humans and dogs live in the city or in the countryside, but wolves live in the forest or in the mountains so they can hunt whenever they want. Dogs are fed by their owners and don't need to hunt. Wolves live in packs organised for hunting; they have a leader who guides them, they mark their territory, defend themselves against intruders, and live in a group. Humans also live in groups in the city, but dogs live alone with their owners in their home. Humans speak, dogs 
bark, wolves howl. Humans live a lot longer than dogs or wolves. Humans can live up to 100 years, dogs 25 years and wolves 30 years."

The quality of writing also often depends on the creativity-transformation potential of the students' ideas, that can be expressed at different times of the writing process (Galbraith, 1999; Hayes, 1996). In other words, while pupils' prior knowledge is used to support the generation of ideas according to the activation model (McArthur et al., 2006), some creativity is involved in this process. Creativity is defined as the ability to produce something that is both new and adapted to the context in which it is manifested (Sternberg \& Lubart, 1995; Villalba, 2008). It is usually measured according to several indicators: fluidity (corresponding to the number of ideas produced), flexibility (referring to the number of categories in which ideas can be classified) and originality (corresponding to the relative statistic scarcity of each proposed idea compared to a reference population) (Lubart, Besançon, \& Barbot, 2011). It has also been well established that creativity can be favoured by a) an artistic referential anchoring (Chabanne, Parayre, Villagordo, \& Dequin, 2011; Leckey, 2017; Slusarczyk, 2017), if the device b) imposes certain constraints (Haught-Tromp, 2017) c) in a limited number, particularly if creativity is assessed in a written text; in this case, proposing open topics facilitates the production of original ideas, since the text has no predetermined plan (Hayes, 2006). Lipman insisted on the role of metaphorical thinking, which he considers to be of an ampliative rather than explanatory type (Lipman, 1995, p.241) and involves a general mechanism of proportionality in the similarities mentioned. So, the creative component of the quality of philosophical writing can be assessed by counting the number of metaphors produced by the writer (Auriac-Slusarczyk et al., 2018; Maire et al., 2018). Moreover, creative thinking is based heavily on the exploratory divergent thinking capacity, i.e. the multi-directional search for a maximum number of ideas or solutions from a simple starting point (Besançon, Barbot, \& Lubart, 2011; see also Lipman, 1995, pp. 233-253). This tendency 
to explore an alternative route may lead to a change in point of view, reversing the direction of a text's local or general reasoning (Cassidy \& Christie, 2013). So, the creative component of the quality of philosophical writing can be assessed by the quality of divergence produced by the writer (Auriac-Slusarczyk et al., 2018; Maire et al., 2018). Some pupils' texts collected in this study exemplify this notion. Thus, when a pupil suddenly adds an alternative idea, he extracts himself from what he had previously presented and writes: "after that, anything is possible"; taking this divergent track, pursuing it and illustrating what is "possible": "cats on two legs, animals that talk". Regular divergence offers alternate paths throughout writing. However, it can also be expressed at the end of the text as a sort of "escape" from all that had been previously written. One student concludes his text with: "I don't really like animals, but whether they are similar to us or not, we need to love them, love them as they love us, and share good times with them and especially enjoy life!!'” (The final divergent proposal appears in bold).

To sum up, the application of good philosophical writing can be studied and measured according to three interrelated components (linguistic, logical and creative) using the indicators used in the literature and listed above.

\section{Objectives and hypotheses}

The long-term goal of this current exploratory study is to introduce an experimental device for philosophical discussion combining art and philosophy in middle school classes (Maire et al., 2018; Slusarczyk, 2017). Thus, this study is preparatory and aims to verify the extent to which artistic support may or may not positively influence the writing process, and to test the possible different impacts of media and topics leading to good philosophical composition among middle school students. The general hypothesis is that the proposed 
writing conditions, combining three media and two topics, can influence writing quality for the targeted linguistic, logical and creative components.

Our hypothesis $\mathrm{H} 1$ focuses on the effect of the media (image, dialogue, key words) on the quality of philosophical writing:

H1a) Linguistic writing quality is not affected by the media, since planning depends on the activation of a developmental and subjective process (Hayes \& Flower, 1980; Scardamalia \& Bereiter, 1991).

H1b) Logical writing quality is not influenced by the media since the philosophical text's macro-structure, like other types of text, is based on a genre structure (Bronckart et al., 1985; Sanders \& Schilperoord, 2006).

H1c) Creative writing quality depends on the media: we expect greater use of metaphors and of divergence with an image that with a dialogue or key words (Chabanne et al., 2011; Leckey, 2017; Slusarczyk, 2017).

Hypothesis $\mathrm{H} 2$ focuses on the effect of the topic (dichotomous: the difference between humans and animals, or not dichotomous: dreams) on the quality of philosophical writing: H2a) Linguistic writing quality is affected by the topic: it is expected that a dichotomous topic encourages step-by-step planning, leading to texts containing more proposals (Auriac \& Favart, 2007) and discursive markers (Fayol, 1985) than a non-dichotomous topic. Still, since we are dealing with 13-14-year-old students for whom the transition to global planning may lead to a shortening of the texts (Hayes \& Flower, 1980; Scardamalia \& Bereiter, 1991), we expect only a tendential effect.

H2b) Logical writing quality is influenced by the topic: it is expected that a dichotomous topic facilitates planning of the text where the writer leans more on differences between concepts, used as an external condition to facilitate the planning of the text (Hayes \& Flower, 1980; Scardamalia \& Bereiter, 1991) than a non-dichotomous topic. 
H2C) Creative writing quality is not affected by the topic, the production of metaphors can be related to the familiar nature of the subject (Haught-Tromp, 2017) allowing the student to freely produce personal ideas (Galbraith, 1999; Hayes, 1996), regardless of the character (dichotomous or not) of the topic.

We have also established a number of secondary hypotheses regarding the effect of controlled variables on the quality of philosophical composition. The linguistic, logical or creative quality of writing: H3) may be influenced by the gender of student (with better writing performance among girls, on the rise in France since 2003; Andreux, Dalibard, \& Etève, 2016; Andreux \& Steimetz, 2017); H4) is not influenced by the grade level of the students, since the grade levels are very close ( $7^{\text {th }}$ grade vs. $8^{\text {th }}$ grade), but H5) might depend on the students' age (if one considers a fine scale, in months, for example), and H6) might be affected by the sector of the students' school, a factor identified as generating academic or learning inequalities (Cousin, 1998; Duru-Bellat \& Mingat, 1988; Felouzis \& Perroton, 2007).

\section{Method}

\section{Participants}

352 middle-school students present in class on the day of the experiment, out of 398 students enrolled in school, participated in the study. There were five classes of 13 year olds ( $7^{\text {th }}$ grade) and ten classes of 14 year olds ( $8^{\text {th }}$ grade) from Auvergne, from five schools from different sectors: two REP+ schools ${ }^{3}$ (disadvantaged socio-economic background), one urban school (privileged socio-economic environment) and two "rurban" schools ${ }^{4}$ (mixed socioeconomic backgrounds). The students wrote a composition preceded by a draft, on a topic (dreams or the difference between humans and animals), from a media (image, dialogue or

\footnotetext{
${ }^{3}$ In France, the term "REP" stands for "Réseaux d'Education Prioritaire" (priority education networks). The number of students per class is lower than in the other sectors (17 on average compared with 25 in favoured sectors).

${ }^{4}$ The term "rurban" is the contraction of "rural" and "urban" and designates schools that are neither completely rural or urban, mid-way between the countryside and the city.
} 
key words). Table 1 shows the distribution of students according to the media and the topic they were provided. We asked the teachers to distribute the media and topics in such a way as to ensure that an equivalent number of students in differentiated French school levels (good, average and poor, according to their academic average) for each media-topic condition.

- Insert here Table 1 -

Table 1. Distribution of compositions as a function of media (image, dialogue, key words) and topic (dreams, the difference between humans and animals).

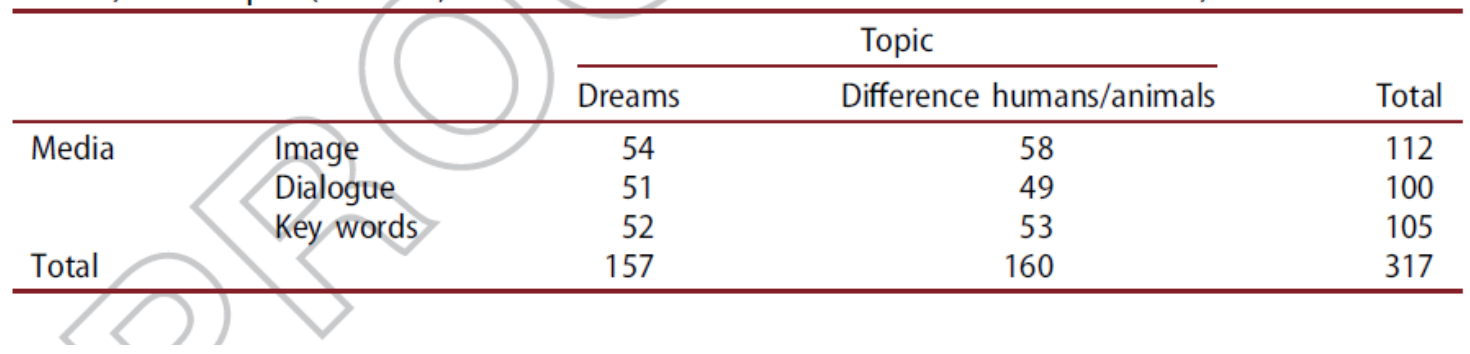

Of the 352 philosophical compositions collected, 35 could not be used due to missing elements: student's gender not indicated (12 compositions), no draft and/or composition (23). Of the 317 remaining compositions studied, the students were aged between 143 and 185 months $\left(M_{a g e}=164\right.$ months, $S D_{a g e}=8$ months $)$, the gender distribution was balanced $(49.8 \%$ girls, $50.2 \%$ boys) and their academic level in French varied from of 4.04 to 18.22 out of 20 $\left(M_{\text {French }}=13\right.$ years, $\left.S D_{\text {French }}=2.79\right)$. Table 2 shows the distribution of these students according to school differentiated by sector and average (REP+ sector corresponding to a disadvantaged socio-economic background, rurban sector reflecting a mixed socio-economic background, urban sector corresponding to a privileged socio-economic environment), and by grade level $\left(7^{\text {th }}, 8^{\text {th }}\right)$.

- Insert here Table 2 - 
Table 2. Distribution of students as a function of grade level $\left(7^{\text {th }}, 8^{\text {th }}\right)$, gender (girls, boys) and schools as a function of average and sector, with sector reflecting socio-economic background (REP + , i.e. disadvantaged socio-economic background, rurban, i.e. mixed socio-economic background, urban, i.e. privileged socio-economic background).

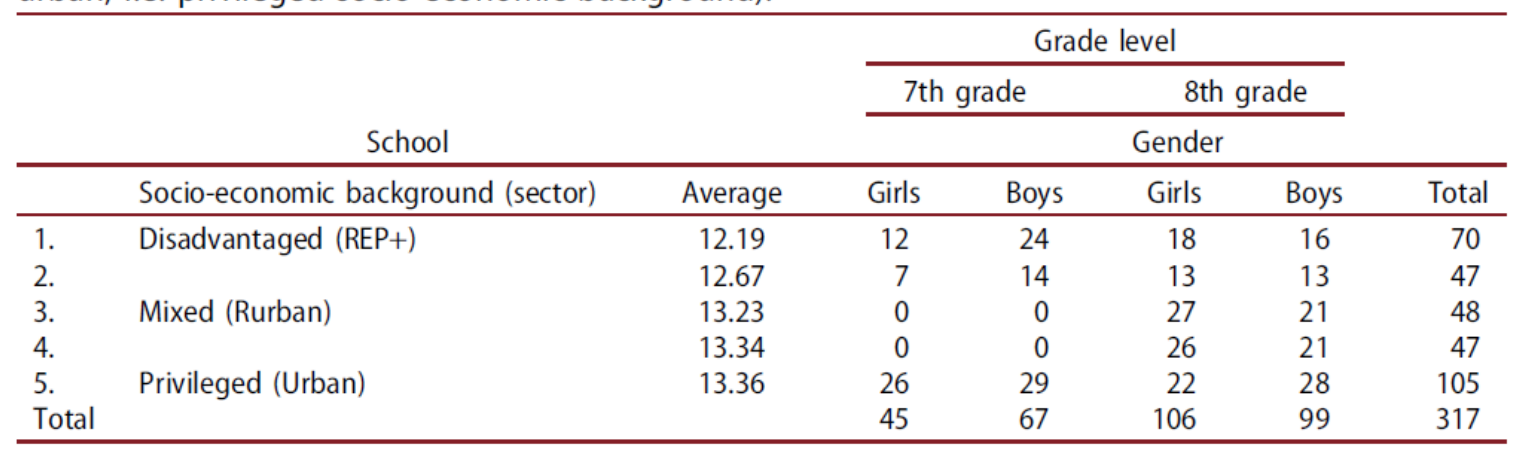

\section{Materials and experimental protocol}

The instructions explicitly invited the students to write for a magazine entitled Adolescence and Society (that was actually published in 2018). They differed according to the topic (Dreams or The difference between humans and animals) and by the media proposed to the student as a source of inspiration (an artistic or media image, a dialogue or three key words). One of the images was the reproduction of a painting by the contemporary painter Etienne Cournault, entitled $L a$ part $d u$ rêve, the other from an illustrated cover from Philosophie magazine, entitled La différence Homme-Animal, subtitled La frontière disparaît, representing a dog in an anthropomorphic position, sitting on a chair. The dialogues were extracted and adapted from Talbot (1999). The three key words were: a) for Dreams: -dream; -hope-worries, (b) for the difference between humans and animals: -dog; -wolf; -human. The key words were chosen because present in the Talbot dialogues (1999), and included equivalent suggestions of distinctions: pet ( $\operatorname{dog}) v s$. wild (wolf), negative aspects (worries) vs. positive (hope). For the difference between humans and animals topic, we were inspired by a study indicating that second year primary students were already able to use appropriately the metaphorical expression "l'homme est un loup pour l'homme" ("man is a wolf for man") (Caillier, 2001). 
The elements characterising the media were placed on the first page (cover) of the notebook and provided in an insert that was then enlarged on the second page (back of the cover), to make it easier to see the image. Page 3 contained a framed space $(15 \times 19 \mathrm{~cm})$ without lines for the outline/rough draft, and included the following instructions, after identifying the topic ("Dreams", or "The difference between humans and animals": "draft to jot down your ideas before writing"). In this way, the suggested outline could be written with the support elements visible. The students then had three pages with 22 pre-drawn lines to write their composition, bearing respectively the words beginning then continued written in upper-case letters above the first line, and a fourth page comprising 11 additional lines indicating "If your text does not fit in the pages, here are a few more lines to finish up", the reference end in upper-case at the end of the lined space. Students wrote for a period of 50 minutes during French class, instructions included.

\section{Dependent and controlled variables}

The quality of philosophical composition was assessed according to fourteen performance indicators in the three targeted interconnected areas (linguistic, logical, creative). Twelve were related to the texts produced by the students, and two their drafts.

Linguistic quality was measured using continuous indicators: (a) length of the text (number of proposals) (b) number of discursive markers in the text, as well as dichotomous indicators: c) presence or absence of an introduction, d) presence or absence of a conclusion, and e) explicit reference to the referential anchor, i.e. the media supplied (Auriac \& Favart, 2007; Fayol, 1985). The length of the draft was also measured in number of proposals.

Logical quality was evaluated using continuous indicators counting a) hypotheses, b) postulates, c) examples,) reasoning and e) concepts (keys ideas) in the text. The number of concepts present in the draft was also counted. A conceptual distinction score was also 
established based on a four levels scale: $0=$ no distinction; $1=$ local distinction; $2=$ regular distinction, step-by-step planning (novice operating mode); $3=$ organisational distinction (expert operating mode) (Scardamalia \& Bereiter, 1991).

Creative quality was measured using two dichotomous indicators noting the presence or absence of (a) one or more metaphors and (b) divergences. This was also assessed by score on a four levels scale: $0=$ no divergence; 1 = local divergence; $2=$ regular divergence; $3=$ final divergence (Auriac-Slusarczyk et al., 2018; Maire et al., 2018).

Controlled variables were: gender (girl, boy), grade level $\left(7^{\text {th }}, 8^{\text {th }}\right)$, age, academic level in French, and socio-economic level reflected by the sector of the establishment $($ disadvantaged $=\mathrm{REP}+$, mixed $=$ rurban, privileged $=$ urban $)$.

\section{Results}

Conventional descriptive and inferential analyses (Chi-squared test, ANOVA) were applied on the data using SPSS 23 software. For all the dichotomous indicators, Chi-squared tests were conducted to test the significance of the differences of the quality of writing between groups as a function of the two studied variables (media: image, dialogue, key words; topic: dreams, the difference between humans and animals) and as function of one controlled variable (sector of the school, reflecting socio-economic background: disadvantaged, mixed, privileged). For all the continuous and dichotomous indicators, onefactor analyses of variance (ANOVA) were applied with the two studied variables separately (media: image, dialogue, key words; topic: dreams, the difference between humans and animals) and two controlled variables separately (gender: boys, girls; grade level: $7^{\text {th }}, 8^{\text {th }}$ ) as a between-subjects factor. Moreover, Pearson correlations were also conducted between logical and creative indicators (see Table 7), since the aim was to define the type of philosophical writing, as well as between all the indicators and the age of the pupils, in order to test how age 
and quality of writing could be correlated or not. Table 3 summarizes the different statistical tests that have been applied.

- Insert here Table 3 -

Table 3. Statistical tests applied for testing the effects of studied variables (media, topic) and controlled variables (gender, grade level, age, school).

\begin{tabular}{|c|c|c|c|c|c|c|c|}
\hline \multirow[b]{2}{*}{$\begin{array}{l}\text { Quality of } \\
\text { writing .... }\end{array}$} & \multirow[b]{2}{*}{$\begin{array}{l}\text { Dichotomous, con- } \\
\text { tinuous and ordinal } \\
\text { variables: }\end{array}$} & \multicolumn{2}{|c|}{ Effects of studied variables } & \multicolumn{4}{|c|}{ Effects of controlled variables } \\
\hline & & $\begin{array}{c}\text { Media (image, } \\
\text { dialogue, key } \\
\text { words) }\end{array}$ & $\begin{array}{l}\text { Topic (dichoto- } \\
\text { mous, not } \\
\text { dichotomous) }\end{array}$ & $\begin{array}{l}\text { Gender } \\
\text { (girls, } \\
\text { boys) }\end{array}$ & $\begin{array}{c}\text { Grade } \\
\text { level } \\
\left(7^{\text {th }}, 8^{\text {th }}\right)\end{array}$ & Age & $\begin{array}{l}\text { School (privi- } \\
\text { leged, mixed, } \\
\text { disadvantaged) }\end{array}$ \\
\hline \multirow[t]{6}{*}{... linguistic: } & Introduction & $x^{2 *}$ & $x^{2}, n s$ & $\begin{array}{l}\text { ANOVA } \\
(F)^{*}\end{array}$ & $\begin{array}{l}\text { ANOVA } \\
(F), n s\end{array}$ & $r^{* *}$ & $x^{2}, n s$ \\
\hline & Conclusion & $x^{2}, n s$ & $x^{2}, n s$ & $\begin{array}{l}\text { ANOVA } \\
(F)^{* *}\end{array}$ & $\begin{array}{l}\text { ANOVA } \\
(F), n s\end{array}$ & $r^{*}$ & $x^{2} * *$ \\
\hline & $\begin{array}{l}\text { Explicit reference to } \\
\text { the referential } \\
\text { anchor }\end{array}$ & $x^{2} * *$ & $x^{2} * *$ & $\begin{array}{l}\text { ANOVA } \\
(F), n s\end{array}$ & $\begin{array}{l}\text { ANOVA } \\
(F), n s\end{array}$ & $r, n s$ & $x^{2}, n s$ \\
\hline & Proposals & ANOVA $(F), n s$ & $\operatorname{ANOVA}(F), n s$ & $\begin{array}{l}\text { ANOVA } \\
\qquad(F) * *\end{array}$ & $\begin{array}{l}\text { ANOVA } \\
(F), n s\end{array}$ & $r^{*}$ & $x^{2}, n s$ \\
\hline & $\begin{array}{l}\text { Proposals in the } \\
\text { draft }\end{array}$ & ANOVA $(F), n s$ & ANOVA $(F)^{*}$ & $\begin{array}{l}\text { ANOVA } \\
(F), n s\end{array}$ & $\begin{array}{l}\text { ANOVA } \\
(F) * *\end{array}$ & $r, n s$ & $x^{2}, n s$ \\
\hline & Discursive markers & ANOVA $(F), n s$ & ANOVA $(F)^{* *}$ & $\begin{array}{l}\text { ANOVA } \\
(F)^{* *}\end{array}$ & $\begin{array}{l}\text { ANOVA } \\
(F), n s\end{array}$ & & $x^{2}, n s$ \\
\hline \multirow[t]{8}{*}{...logical: } & Hypotheses & $x^{2}, n s$ & $x^{2}, n s$ & $\begin{array}{l}\text { ANOVA } \\
(F), n s\end{array}$ & $\begin{array}{l}\text { ANOVA } \\
(F), n s\end{array}$ & & $x^{2} * *$ \\
\hline & Postulates & $x^{2}, n s$ & $x^{2}, n s$ & $\begin{array}{l}\text { ANOVA } \\
\quad(F), n \text { s. }\end{array}$ & $\begin{array}{l}\text { ANOVA } \\
(\theta, n s\end{array}$ & r. ns & $x^{2} * *$ \\
\hline & Examples & $x^{2}, n s$ & $x^{2}, n s$ & $\begin{array}{l}\text { ANOVA } \\
(F), n s\end{array}$ & $\begin{array}{r}\text { ANOVA } \\
(F), n S\end{array}$ & $r^{*}$ & $x^{2 *}$ \\
\hline & Reasoning & $x^{2}, n s$ & $x^{2}, n s$ & $\begin{array}{l}\text { ANOVA } \\
(F), n s\end{array}$ & $\begin{array}{l}\text { ANOVA } \\
(F, n S\end{array}$ & $r, n s$ & $x^{2} * *$ \\
\hline & Concepts & ANOVA $(F), n s$ & ANOVA $(F), n s$ & $\begin{array}{l}\text { ANOVA } \\
(F)^{*}\end{array}$ & $\begin{array}{l}\text { ANOVA } \\
(F) * *\end{array}$ & $r^{* *}$ & $x^{2}, n s$ \\
\hline & $\begin{array}{l}\text { Concepts in the } \\
\text { draft }\end{array}$ & ANOVA $(F), n s$ & ANOVA $(F)^{*}$ & $\begin{array}{l}\text { ANOVA } \\
(F), n s\end{array}$ & $\begin{array}{l}\text { ANOVA } \\
(F)^{*}\end{array}$ & $r$, ns & $x^{2 *}$ \\
\hline & $\begin{array}{l}\text { Distinctions } \\
\text { (presence/ } \\
\text { absence) }\end{array}$ & $x^{2}, n s$ & $x^{2} * *$ & $\begin{array}{l}\text { ANOVA } \\
(F), n s\end{array}$ & $\begin{array}{l}\text { ANOVA } \\
(F), n s\end{array}$ & $r^{* *}$ & $x^{2}, n s$ \\
\hline & Distinctions (score) & ANOVA $(F), n s$ & ANOVA $(F)^{* *}$ & $\begin{array}{l}\text { ANOVA } \\
(F), n s\end{array}$ & $\begin{array}{l}\text { ANOVA } \\
(F), n s\end{array}$ & $r, n s$ & $x^{2}, n s$ \\
\hline \multirow[t]{3}{*}{...creative: } & Metaphors & $x^{2 *}$ & $x^{2 *}$ & $\begin{array}{l}\text { ANOVA } \\
(F)^{*}\end{array}$ & $\begin{array}{l}\text { ANOVA } \\
(F), n s\end{array}$ & $r, n s$ & $x^{2}, n s$ \\
\hline & $\begin{array}{l}\text { Divergence } \\
\text { (presence/ } \\
\text { absence) }\end{array}$ & $x^{2 *}$ & $x^{2}$ & $\begin{array}{l}\text { ANOVA } \\
(F), n s\end{array}$ & $\begin{array}{l}\text { ANOVA } \\
\qquad(F), n s\end{array}$ & $r, n s$ & $x^{2}, n s$ \\
\hline & Divergence (score) & ANOVA $(F)^{*}$ & ANOVA $(F)^{*}$ & $\begin{array}{l}\text { ANOVA } \\
(F), n s\end{array}$ & $\begin{array}{l}\text { ANOVA } \\
(F), n s\end{array}$ & $r, n s$ & $x^{2}, n s$ \\
\hline
\end{tabular}

Note. " $\chi^{2 "}$ means Chi-squared test. "ANOVA" means one-factor analysis of variance. " $r$ " means Pearson correlation test. *: $p<.05 .{ }^{* *}: p<.01$. Grey boxes contain significant results (or results that tend to be significant) that are commented on further in the paper.

Numbers and means of all the indicators are presented in Tables 4, 5 and 6, with the dichotomous variables, then continuous variables, and finally ordinal variables, respectively.

- Insert here Table 4 - 
Table 4. Numbers of texts containing dichotomous indicators of linguistic, logical and creative quality of writing as a function of media (image, dialogue, key words) and topic (dreams, the difference between humans and animals).

\begin{tabular}{|c|c|c|c|c|c|c|c|}
\hline \multirow[b]{2}{*}{$\begin{array}{l}\text { Quality of } \\
\text { writing .... }\end{array}$} & \multirow[b]{2}{*}{ Dichotomous variables: } & \multicolumn{2}{|c|}{ Image } & \multicolumn{2}{|c|}{ Dialogue } & \multicolumn{2}{|c|}{ Key words } \\
\hline & & Dreams & $\begin{array}{l}\text { Humans- } \\
\text { animals }\end{array}$ & Dreams & $\begin{array}{l}\text { Humans- } \\
\text { animals }\end{array}$ & Dreams & $\begin{array}{l}\text { Humans- } \\
\text { animals }\end{array}$ \\
\hline \multirow{7}{*}{$\begin{array}{l}\text {...linguistic: } \\
\text { logical: }\end{array}$} & Introduction & 17 & 25 & 15 & 9 & 14 & 14 \\
\hline & Conclusion & 19 & 32 & 20 & 21 & 16 & 29 \\
\hline & $\begin{array}{l}\text { Explicit reference to the } \\
\text { referential anchor }\end{array}$ & 20 & 10 & 11 & 5 & 7 & 3 \\
\hline & Hypotheses & 14 & 20 & 7 & 15 & 9 & 12 \\
\hline & Postulates & 39 & 54 & 35 & 46 & 40 & 38 \\
\hline & Examples & 26 & 37 & 20 & 34 & 26 & 17 \\
\hline & Reasoning & 23 & 36 & 21 & 30 & 20 & 36 \\
\hline \multirow[t]{2}{*}{...creative: } & Metaphors & 16 & 14 & 14 & 1 & 11 & 8 \\
\hline & Divergence & 29 & 34 & 25 & 24 & 17 & 25 \\
\hline
\end{tabular}

- Insert here Table 5 -

Table 5. Mean numbers per text of continuous indicators of linguistic and logical quality of writing as a function of media (image, dialogue, key words) and topic (dreams, the difference between humans and animals).

\begin{tabular}{|c|c|c|c|c|c|c|c|}
\hline \multirow[b]{2}{*}{$\begin{array}{l}\text { Quality of } \\
\text { writing... }\end{array}$} & \multirow[b]{2}{*}{$\begin{array}{l}\text { Continuous } \\
\text { variables: }\end{array}$} & \multicolumn{2}{|c|}{ Image } & \multicolumn{2}{|c|}{ Dialogue } & \multicolumn{2}{|c|}{ Key words } \\
\hline & & Dreams & $\begin{array}{c}\text { Humans- } \\
\text { animals }\end{array}$ & Dreams & $\begin{array}{l}\text { Humans- } \\
\text { animals }\end{array}$ & Dreams & $\begin{array}{l}\text { Humans- } \\
\text { animals }\end{array}$ \\
\hline \multirow[t]{3}{*}{...linguistic: } & Proposals & 21.9 & 23.7 & 23.2 & 21.1 & 20.3 & 22.8 \\
\hline & $\begin{array}{l}\text { Proposals in the } \\
\text { draft }\end{array}$ & 10.3 & 11.3 & 9.6 & 10.4 & 9.8 & 11.6 \\
\hline & Discursive markers & 5.1 & 7.4 & 5.4 & 6.2 & 5.0 & 7.2 \\
\hline \multirow[t]{2}{*}{...logical: } & Concepts & 24.4 & 267 & 25.0 & 25.2 & 23.2 & 25.9 \\
\hline & $\begin{array}{l}\text { Concepts in the } \\
\text { draft }\end{array}$ & 13.9 & & 12.4 & 15.4 & 13.6 & 14.9 \\
\hline
\end{tabular}

- Insert here Table 6 -

\begin{tabular}{|c|c|c|c|c|c|c|c|c|}
\hline \multirow[b]{2}{*}{$\begin{array}{l}\text { Quality of } \\
\text { writing... }\end{array}$} & & & \multicolumn{2}{|c|}{ Image } & \multicolumn{2}{|c|}{ Dialogue } & \multicolumn{2}{|c|}{ Key words } \\
\hline & & variables: & Dreams & $\begin{array}{c}\text { Humans- } \\
\text { animals }\end{array}$ & Dreams & $\begin{array}{l}\text { Humans- } \\
\text { animals }\end{array}$ & Dreams & $\begin{array}{l}\text { Humans- } \\
\text { animals }\end{array}$ \\
\hline \multirow[t]{4}{*}{...logical: } & Conceptual & No distinction & 25 & 8 & 24 & 3 & 29 & 6 \\
\hline & & Local distinction & 14 & 8 & 14 & 5 & 7 & 10 \\
\hline & & $\begin{array}{l}\text { Regular } \\
\text { distinction }\end{array}$ & 4 & 26 & 6 & 26 & 8 & 23 \\
\hline & & $\begin{array}{c}\text { Organisational } \\
\text { distinction }\end{array}$ & 11 & 16 & 7 & 15 & 18 & 14 \\
\hline \multirow{4}{*}{\multicolumn{2}{|c|}{...creative: }} & No divergence & 25 & 24 & 26 & 25 & 35 & 28 \\
\hline & & Local divergence & 9 & 6 & 8 & 6 & 5 & 6 \\
\hline & & $\begin{array}{l}\text { Regular } \\
\quad \text { divergence }\end{array}$ & 8 & 7 & 8 & 2 & 5 & 5 \\
\hline & & Final divergence & 12 & 21 & 9 & 16 & 7 & 14 \\
\hline
\end{tabular}

\section{Correlations between logical and creative indicators}

The correlations between logical and creative indicators indicate that the logical indicators were all significantly positively correlated, and each was positively correlated to the presence of divergence, i.e. the creative indicator (see Table 7).

- Insert here Table 7 - 
Table 7. Correlation matrix between some indicators of logical quality (hypotheses, reasoning, postulates, examples) and one indicator of creative quality (divergences).

\begin{tabular}{lccccc}
\hline & Hypotheses & Reasoning & Postulates & Examples & Divergences \\
\hline Hypotheses & 1 & $.263^{* *}$ & $.200^{* *}$ & $.154^{* *}$ & $.247^{* *}$ \\
Reasoning & & 1 & $.326^{* *}$ & $.252^{* *}$ & $.219^{* *}$ \\
Postulates & & 1 & $.420^{* *}$ & $.140^{* *}$ \\
Examples & & & & 1 & $.122^{*}$ \\
Divergences & & & & & 1 \\
\hline Note: ${ }^{*}: p<.05 .{ }^{* *}: p<.01$. & & &
\end{tabular}

\section{Influence of the media on the quality of philosophical composition}

The selected media type (image, dialogue, key words) partially affected the linguistic quality of writing, contradicting our hypothesis H1a. The media had a trend effect on the presence of an introduction to the text $\left(\chi^{2}(1,316)=5.29, p=.07\right)$, with the introduction seeming to be favoured by the image: as Figure 1 indicates, there were more texts with an introduction written by students using an image that by students using a dialogue or key words. Students having written based on an image were also more likely to have explicitly referred to the referential anchor, mentioning the media in their text, that those writing based on a dialogue or key words: $\chi^{2}(1,316)=11.38, p=.003$ (see Figure 1). In contrast, the other indicators of linguistic quality (length of the text and draft, number of discursive markers, presence or absence of a conclusion) did not vary according to the type of media provided.

The media did not influence the logical quality of the compositions in agreement with hypothesis H1B: all of the logical indicators (hypotheses, postulates, examples, reasoning, concepts in the text, concepts in the draft, distinctions) were produced in similar proportions regardless of the media provided.

Finally, the media had an effect on the creative quality of the texts, validating hypothesis H1C: students having written based on an image tend to be more likely to produce divergences (63 students) than those who received a dialogue (49 students) or key words (42 students): $\chi^{2}(1,316)=5.73, p=.06$. Moreover, the media significantly affected the score of divergence: $F(2,315)=5.18, p=.02, \eta_{\mathrm{p}}^{2}=0.02$. Similarly, the production of metaphors tended to be affected by the type of media: half (30) of the 64 students having used metaphors 
were among those having written based on an image, compared with 15 students writing based on the dialogue, and 19 students writing based on key words: $\chi^{2}(1,316)=5.16, p=$ .07.

- Insert here Figure 1 -
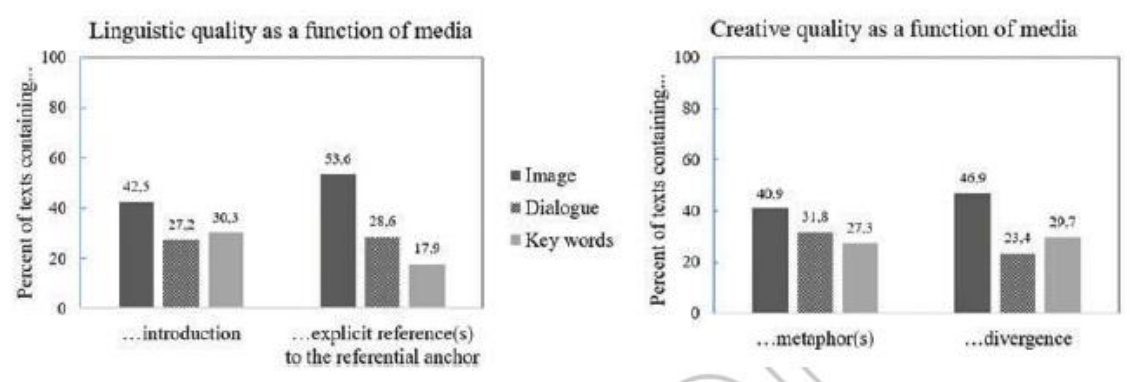

Figure 1. Percentages of texts containing an introduction, one or more explicit reference(s) to the referential anchor, one or more metaphor(s), and divergences, as a function of media (image, dialogue, key words).

To sum up, the image media is tendentially different from the verbal media (dialogue, key words), promoting linguistic quality (introduction, referential anchor) and creative quality (divergences, metaphors).

\section{Influence of the topic on the quality of philosophical writing}

In partial agreement with hypothesis $\mathrm{H} 2 \mathrm{a}$, the results indicate that the topic provided (dichotomous or not) did not drastically affect the linguistic quality of writing. However, the use of discursive markers was facilitated by a dichotomous topic: $F(2,315)=8.67, p=.003$, $\eta_{\mathrm{p}}{ }^{2}=0.02$. The topic did influence linguistic quality of the drafts. The drafts contained more proposals when the students were asked to write about the difference between humans and animals than about dreams: $F(2,315)=5.95, p=.01, \eta_{\mathrm{p}}{ }^{2}=0.02$. Thus, fluidity and discursive organization could be facilitated by a dichotomous topic in the early stages of idea planning (draft), but no impact on the length of the final text has been observed. On the other hand, more of the students who wrote about dreams explicitly mentioned the media in their text (38 students) than those who wrote about the difference between humans and animals (16 students $): \chi^{2}(1,316)=9.14, p=.002$. 
Furthermore, the results highlight a topic effect on the logical quality of the draft: the students writing on the difference between humans and animals produced more concepts $(F$ $\left.(2,315)=4.07, p=.04, \eta_{\mathrm{p}}^{2}=0.01\right)$ than the students having written on the topic of dreams. On the other hand, there was no significant difference in the production of concepts in the texts. In agreement with our hypothesis $\mathrm{H} 2 \mathrm{~B}$, the topic did influence the production of distinctions between concepts. Of the 232 students having made distinctions, more students wrote about the difference between humans and animals (143 students) than about dreams (89 students): $\chi^{2}(1,316)=43.14, p<.0001$. The students who wrote about the difference between humans and animals were also more likely to have made final distinctions (i.e., the highest level on our scale) than the students who wrote about dreams: $\mathrm{F}(2,315)=42.48, p<.0001$, $\eta_{\mathrm{p}}{ }^{2}=0.48$. In comparison, the dreams topic led the 157 students concerned to 1 ) generally not introduce any distinction (68 students, compared with 17 among students having written on the difference between humans and animals), or 2) produce local distinctions (35 students, compared with 23 students who wrote about the difference between humans and animals) or organisational distinctions (36 students, against 45 of those having written on the difference between humans and animals). Students writing about dreams massively ignored the step-bystep planned distinction (just 18 students), which on the other hand, was used more broadly by 75 of the 160 students writing about the difference between humans and animals.

Concerning the creative dimension, contrary to our hypothesis $\mathrm{H} 2 \mathrm{c}$ and as shown in Figure 2, the level of divergence varied significantly according to the topic: $F(2,315)=4.49$, $p=.04, \eta_{\mathrm{p}}^{2}=0.01$. In particular, a high degree of divergence (final divergence, i.e. highest degree on our scale) was more frequently introduced by students writing about the difference between humans and animals than by those writing about dreams. Furthermore, the number of texts containing at least one metaphor was significantly higher among students writing about 
dreams (41 students) than among those writing about the difference between humans and animals $(23$ students $): \chi^{2}(1,316)=6.93, p=.006$.

- Insert here Figure 2 -

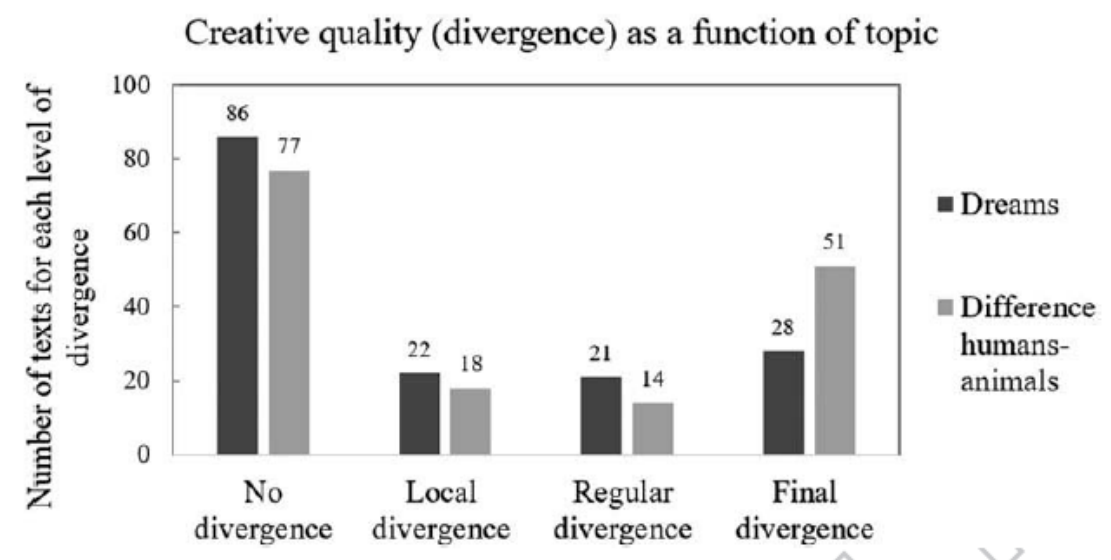

Figure 2. Numbers of texts containing each level of divergence (none, local, regular, final) as a function of topic (dreams, the difference between humans and animals).

In short, the nature of the topic leads to differences in the linguistic, logical and creative writing process. Writing about a dichotomous topic leads students to implement more global planning, with higher distinction and divergence scores and the use of more of concepts right from the draft. In contrast, writing about a non-dichotomous led topic students to use more metaphors, and, for students generating divergent thinking, to activate a divergence linked to a more step-by-step form of planning (local or regular).

\section{Effects of the controlled variables}

\section{The effect of gender}

The quality of philosophical writing was influenced by the students' gender, validating our secondary hypothesis H3: girls wrote longer texts $\left(F(1,315)=22.45, p<.0001, \eta_{\mathrm{p}}^{2}=0.07\right)$, produced more concepts $\left(F(1,135)=5.81, p<.02, \eta_{\mathrm{p}}^{2}=0.02\right)$, introduced more frequently their text $\left(F(1,135)=4.78, p<.03, \eta_{\mathrm{p}}^{2}=0.02\right)$, used more discursive markers $(F(1,135)=$ $\left.15.64, \mathrm{p}<.0001, \eta_{\mathrm{p}}{ }^{2}=0.05\right)$, and concluded more frequently their text $(F(1,135)=6.64, p<$ 
$.01, \eta_{\mathrm{p}}^{2}=0.02$ ) than the boys (see Figure 3). Girls tended to have an advantage in the production of metaphors $(F(1,135)=3.18, p=.07)$, in agreement with previous results observed in primary school students (Auriac-Slusarscyk et al., 2018).

- Insert here Figure 3 -

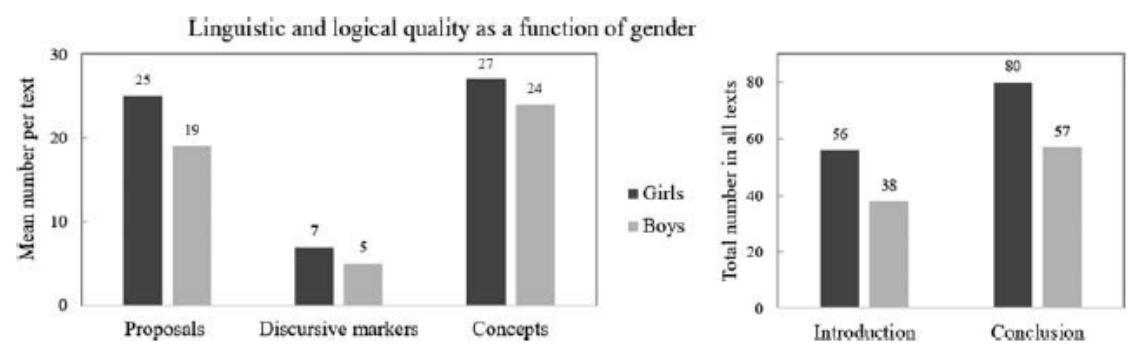

Figure 3. Mean numbers of indicators of linguistic quality (proposals, discursive markers, introduction, conclusion) and indicators of logical quality of texts (concepts) as a function of gender of students (boys, girls).

\section{The effect of grade level}

In agreement with our secondary hypothesis $\mathrm{H} 4$, this effect concerns few indicators (see Figure 4). The drafts of $8^{\text {th }}$ grade students included more proposals $(F(1,135)=8.06, p<.01$, $\left.\eta_{\mathrm{p}}{ }^{2}=0.03\right)$, and tended to contain more concepts $(F(1,135)=3.78, p=.06)$ than those of students in $7^{\text {th }}$ grade. However, at the same time, $7^{\text {th }}$ grade texts contained more concepts $(F$ $\left.(1,135)=8.77, p<.01, \eta_{\mathrm{p}}^{2}=0.03\right)$.

- Insert here Figure 4 -

Linguistic and logical quality as a function of grade level

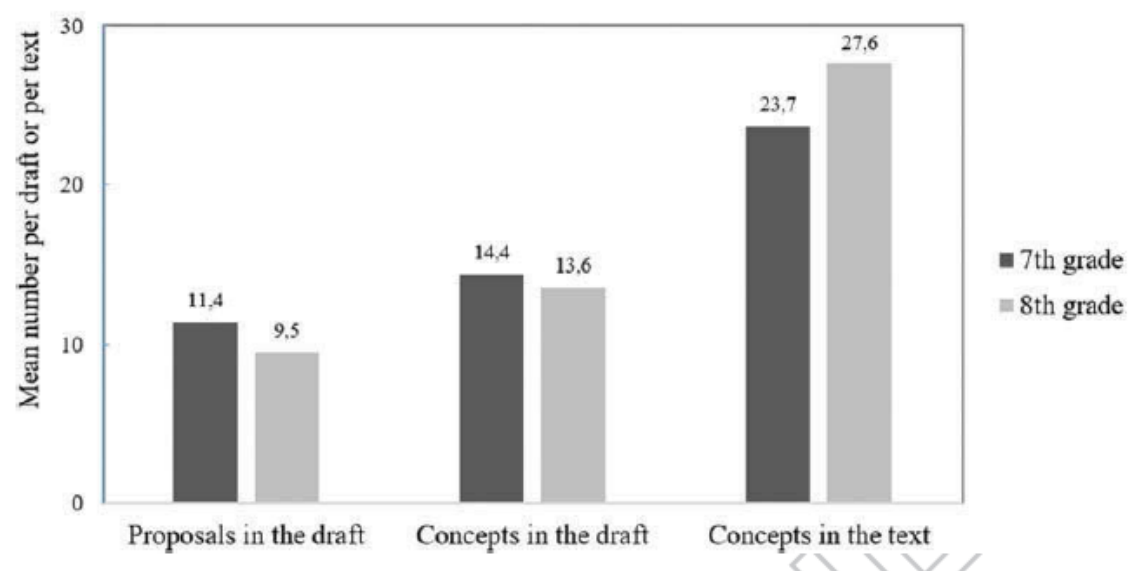

Figure 4. Indicators of linguistic quality (mean numbers of proposals per draft) and indicators of logical quality (mean numbers of concepts per draft and per text) as a function of grade level of students (7th, 8 th). 


\section{The effect of age}

The students' age was negatively correlated to linguistic and logical performance in agreement with our secondary hypothesis H5. In other words, the older they were, the less likely the students were to write a long text $(r=-.145, p=.01)$, to have an introduction $(r=-$ $.249, p=.00001)$, to have a conclusion $(r=-.136, p=.01)$, to produce concepts $(r=-.207, p=$ $.00001)$, to make organisational distinctions between them $(r=-.184, p=.001)$, and to offer examples $(r=-.144, p=.01)$.

\section{The effect of the school}

Only $8^{\text {th }}$ grade students were considered in this part, i.e. 205 students, since there were too few $7^{\text {th }}$ grade students to be included in the analyses. The average of each establishment is paralleled with the results (see Table 2). Two main results emerge regarding the school effect (H6) on the logical quality, and, to a lesser extent, on the linguistic quality of the compositions. On the one hand, two schools (one rurban, $M=13.34$, the other urban, $M=13.36$ ) had significantly better performance than the others. The students from these two schools generated more concepts right from the draft $\left(\chi^{2}(124,81)=152.62, p=.04\right)$, more postulates $\left(\chi^{2}(4,201)=17.58, p=.001\right)$, more hypotheses $\left(\chi^{2}(4,201)=24.09, p<.000\right)$, more reasoning $\left(\chi^{2}(4,201)=16.71, p=.002\right)$ (see Figure 5 for example) and concluded their texts more $\left(\chi^{2}(4,201)=16.19, p=.003\right)$. Furthermore, the students from two contrasting schools (one from a REP+ disadvantaged environment, $M=12.67$, the other from the privileged urban environment, $M=13.36$ ) supported their text with more examples that did students from the other schools $\left(\chi^{2}(4,201)=9.57, p=.048\right.$; see Figure 5).

- Insert here Figure 5 - 

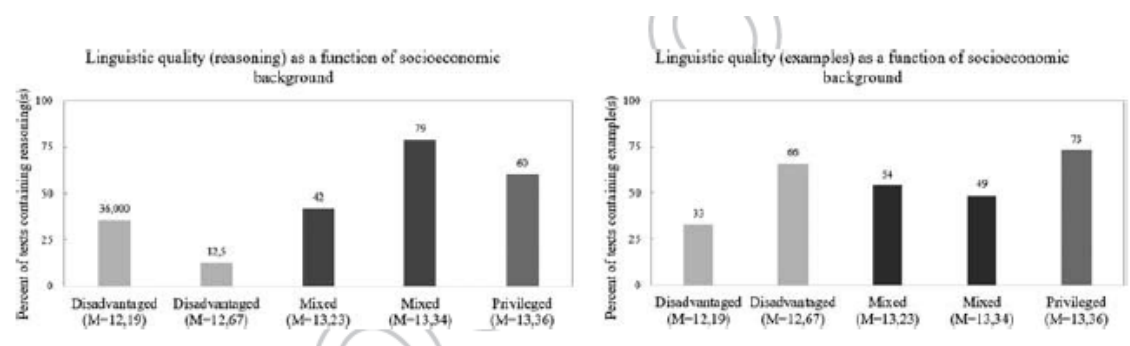

Figure 5. Percentage of indicators of logical quality (reasoning, examples) as a function of socioeconomic background of the school, with recall of average per school (REP+, i.e. disadvantaged socio-economic background: $\mathrm{M} 1=12.19, \mathrm{M} 2=12.67$; rurban, i.e. mixed socio-economic background: M3 = 13.23, M4 = 13.34; urban, i.e. privileged socio-economic background: M5 = 13.36).

\section{Discussion}

This exploratory study aimed to compare the conditions favourable to obtaining high quality philosophical compositions, using a set of selected indicators to determine the quality of philosophical writing. We assume that this orientation of research is crucial to think a putative redesign of middle school curriculum. Our study aimed to highlight the conditions that engage both teachers and students to improve quality of writing and could be adapted with other medias or topics. Our results show that quality depends on the topic and media provided, emphasising the crucial nature of the material used to allow good philosophical composition. It appears that allowing students to write from an image and on a familiar nondichotomous topic (dreams) allows them to explicitly exploit the media as a referential anchor, to introduce their text, generate metaphors and divergence. On the other hand, proposing a familiar topic in dichotomous form (the difference between humans and animals) invites students to exploit the suggested distinctions to conceptualize right from the draft and then plan their text in a more comprehensive manner, and direct their text to a final divergent proposal. These results can provide new directions for teaching composition in middle school, going beyond the formats and frameworks often imposed on these students. Indeed, teachers often need help to make proper choices in order to improve quality of writing and to implement efficiently practices of writing (see Newell, Koukis, \& Boster, 2007). The current study encourages teachers to test original and complementary conditions to enhance and to diversify quality of writing. 
In terms of planning ability (cf. Hayes \& Flowers, 1980; Scardamalia \& Bereiter, 1991), we find, among others, possible indications of a transition to a more comprehensive planning mode starting in $8^{\text {th }}$ grade, a crucial stage with regard to this type of skill. At this level of schooling, students would be more likely to generate most of their ideas in the draft, then organise them in directed textual planning later on (focussing the reasoning on the useful concepts). Students in $7^{\text {th }}$ grade generate slightly fewer ideas but plan their text in a more linear manner (renewing ideas when writing; cf. Auriac \& Favart, 2007). In this sense, our study is rather a confirmation of theoretical developmental steps. Furthermore, older students seem to move away gradually from certain aspects of formal quality associated with the lengthening of the texts: introduction, conclusion, conceptualisation, exemplification. Further investigations are needed in order to confirm this trend and to test whether the rejection of formal quality is relevant with developmental steps or with teachers' choices.

While performance by school is different, our results do not reveal any clear weight of the school on their students' composition performance. In line with previous studies (cf. Cousin, 1998; Duru-Bellat \& Mingat, 1988; Felouzis \& Perroton, 2007), pupils from privileged or mixed socioeconomic backgrounds, who have better average academic performance, are more able to produce higher logical and linguistic quality of writing. However, the current findings indicate that disadvantaged and privileged socioeconomic backgrounds can not be opposed in a simplistic way. For instance, the use of examples by pupils from both of these contrasting backgrounds highlights the possibility to renew or to repeat comparisons. The pattern obtained for examples (i.e., good performance for disadvantaged school) might rather be seen as the result of a direct benefit of the instruction to write freely in a universal form; this spontaneous production of disadvantaged students falls within philosophical openness (Chabanne, 2002; Gorard et al., 2017). However, for the methodology of future studies, this pattern invites us to prioritise examples in various 
categories, for example distinguishing personal anecdotes from general examples, with a more universalist scope (Maire et al., 2018).

The observed gender effect corroborates the gap between girls and boys already observed in previous works on the production of metaphors in philosophical composition among younger students (cf. Auriac-Slusarczyk et al., 2018), as well as growing work in the entire academic sphere (cf. Andreux et al., 2016; cf. Andreux \& Steimetz, 2017). The replication of this effect in the current study points out the need to encourage teachers to adapt the education modalities to the specific needs for both girls and boys. Research in the field of written production, including research on teachers' practices (see Graham, McArthur \& Fitzgerald, 2007), have possibly too massively emphasized theoretical models through the different levels of planning, evaluation, revision, etc. (cf. Alamargot \& Chanquoy, 2001). Rather, it is likely that studies about the links between gender attitude and written strategies could contribute to equalize performances between girls and boys.

This study may be seen as a starting point for opening future investigations, with the compositions collected on this occasion being added to in coming school years (see http://philosophemes.univ-bpclermont.fr). In view of future research, it would be useful to deepen the study of the use of metaphors, distinguishing between uses related to aesthetics and explanatory ones, as differentiating factor of thought creative planning in children (Hofstadter \& Sander, 2013). Successful students would probably use more aesthetic metaphors, sprucing up their texts in order to meet academic demands to use "beautiful" language. Similarly, distinguishing inherited metaphors ("raining cats and dogs", "walking on eggshells") reflecting the writer's level of language proficiency (see Rey, Romain, \& DeMartino, 2015) from inventive metaphors, indicating creativity (cf. Sternberg \& Lubart, 1999) would make it possible to assess more finely the linguistic and creative quality of compositions. Finally, the material used (media, topic) should also be diversified, such as 
different types of images (works of art, media image, etc.) in order to solidly establish these initial research results. Considering writing as a way toward the exercise of responsibility and as a key tool for future social integration (see Newell et al., 2007), the current study encourages teachers to take advantage of various strategies in order to engage their students to innovate and to develop their critical reasoning skills.

Acknowledgments: The authors thank Julie Pironom, research engineer at Laboratoire ACTé, for her advice on certain statistical analyses. This study is part of the COPHILEC (2016-2019) research project, funded under the experimental creation phase in the greater Auvergne-Rhône-Alpes region of Instituts Carnot de l'Education, aimed to bring together educational projects (schools) and research projects (humanities and social sciences laboratories).

Conflict of interest statement: The authors declare no conflict of interest.

\section{Références bibliographiques}

Alamargot D., \& Chanquoy. L., (2001). Through the models of writing (Vol 9). Dordrecht, Boston, London : Kluwer Academic Publischers.

Alkhatib, M. (2012). La cohérence et la cohésion textuelles : problème linguistique ou pédagogique ? Didáctica. Lengua y Literatura, 24, 45-64. doi:10.5209/rev_DIDA.2012.v24.39916

Andreux, S., Dalibard, E., \& Etève, Y. (2016). Maîtrise de la langue en fin d'école : l'écart se creuse entre filles et garçons. Évaluation des acquis des élèves. Note d'information de la Direction de l'Evaluation de la Prospectives et des Partenariats, 20.

Andreux, S., \& Steinmetz, C. (2017). Evaluation et statistiques. Les performances en orthographe des élèves en fin d'école primaire (1987-2007-2015). Note d'information de la Direction de l'Evaluation, de la Prospective et de la Performance, 28. 
Auguet, G. (2003). La discussion à visée philosophique aux cycles 2 et $3:$ un genre nouveau en voie d'institution? Thèse de doctorat. Université Montpellier 3, Montpellier.

Auriac, E. (2007) Effet de discussions à visée philosophique sur le processus de génération d'idées. Enfance, 2007(4), 356-370.

Auriac, E., \& Favart, M. (2007). Passage d'un avant-texte au texte dans des écrits scolaires de type argumentatif. Langue Française, 115(3), 69-83. doi:10.3917/lf.155.0069

Auriac-Peyronnet E., \& Daniel M.-F. (2005). Impact of regular philosophical discussion on argumentative skills: Reflection about education in primary schools. In G. Rijlaarsdam (Ed.), Studies in Writing (Vol. 14) (pp.291-304). Dordrecht: Kluwer Academic Publishers.

Auriac-Peyronnet, E., \& Daniel, M.-F. (2009). Apprendre à dialoguer avec des élèves : le cas des dialogues philosophiques. Psychologie de l'Interaction, $N^{\circ}$ spécial 25-26, 155-196.

Auriac-Slusarczyk, E., \& Colletta, J.-M. (2015). Les ateliers de philosophie : une pensée collective en acte. Clermont Ferrand : Presses Universitaires Blaise Pascal.

Auriac-Slusarczyk, E., Slusarczyk, B., Thebault, C., \& Pironom, J. (2018). Premiers écrits philosophiques. Productivité conceptuelle et créativité rédactionnelle du CE2 au CM2. Bulletin de Psychologie, 3, 671-690.

Bakhtine, M. (1978). Esthétique et théorie du roman. Paris : Gallimard.

Beausoleil J.-R., \& Daniel M.-F., (1991), L'identification des dimensions philosophiques dans les dialogues des élèves. Arrimages, 7 et 8, 17-23.

Besançon, M., \& Barbot, B. (2011). EPOC. Evaluation du POtential Creative de Lubart et collaborateurs. Paris : Editions Hogrefe.

Besançon, M., Barbot, B., \& Lubart, T. (2011). Évolution de l'évaluation de la créativité chez l'enfant de Binet à nos jours. Recherches et Educations, 5, 215-226.

Bronckart, J.-P., Bain, D., Schneuwly, B., Davaud, C., \& Pasquier, A. (1985). Le fonctionnement des discours: Un modèle psychologique et une méthode d'analyse. Neuchâtel : Delachaux \& Niestlé.

Caillier, J. (2001). Le courant «maîtrise de la langue » ? In M. Tozzi (Ed.), L'éveil de la pensée réflexive à l'école primaire (pp. 61-68). Paris: Hachette \& Montpellier: CRDP. 
Cassidy, C., \& Christie, D. (2013). Philosophy with children: Talking, thinking and learning together. Early Child Development and Care, 183(8), 1072-1083. doi:10.1080/03004430.2013.773509

Choulet, P., Folscheid, D., \& Wunenbuger, J-J. (1992). Méthodologie philosophique. Paris: Presses Universitaires de France.

Chabanne, J.-C. (2002). Écrire en ZEP. Un autre regard sur les écrits des élèves. Paris: Delagrave.

Chabanne, J.-C., Parayre, M., Villagordo, E., \& Dequin, P. (2011). Premiers pas dans la parole sur l'œuvre : Observer, interpréter et guider les conduites langagières comme compétence professionnelle. Repères. Recherche en Didactique du Français Langue Maternelle, 43, 77-102.

Coirier P., Favart M., \& Chanquoy, L. (2002). Ordering and structuring ideas in text: From conceptual organization to linguistic formulation. European Journal of Education Psychology, 17(2), 157-175. doi:10.1007/BF03173256

Çokluk-Bökeoğlu, Ö. (2008). Testing factor structure of California Measure of Mental Motivation Scale. World Applied Sciences Journal, 4(1), 94-99.

Colom, R., Moriyón, F. G., Magro, C., \& Morilla, E. (2014). The long-term impact of Philosophy for Children: A longitudinal study (preliminary results). Analytic Teaching and Philosophical Praxis, $35(1), 50-56$.

Cousin, O. (1998). L'efficacité des collèges. Paris : Presses Universitaires de France.

Daniel M.-F., (1992/1997). La philosophie et les enfants, Les modèles de Lipman et de Dewey. Montréal : Logiques \& Bruxelles : DeBoeck \& Belin.

Daniel M.-F., (2003). Une coopération de haut niveau : l'exemple de la philosophie pour enfants. In E. Auriac-Peyronnet (Ed.), Je parle, tu parles, nous apprenons. Coopération et argumentation au service des apprentissages (pp. 238-250). Bruxelles: De Boeck Université.

Daniel, M.-F. (2005). Pour l'apprentissage d'une pensée critique au primaire. Sainte-Foy : Presses de l’Université du Québec.

Daniel, M.-F., \& Pallascio, R. (1997). Community of inquiry and community of philosophical inquiry: Conceptual analysis and application to the children's classroom. Inquiry the Journal of Critical Thinking, 17(1), 51-67. 
Dolz, J., \& Schneuwly, B. (1998). Pour un enseignement de l'oral. Initiation aux genres formels à l'école. Paris : ESF Editeur.

Doquet-Lacoste, C. (2009). Écrits intermédiaires, écritures intermittentes. Carnets, notes, bribes de science, Langage et Société, 127(1), 7-22.

Duru-Bellat, M., \& Mingat, A. (1988). Le déroulement de la scolarité au collège : le contexte 'fait des différence'. Revue Française de Sociologie, 29(4), 649-666.

Fayol, M. (1985). Le récit et sa construction: une approche de psychologie cognitive. Neuchâtel, Paris: Delachaux et Niestlé.

Fayol, M. (1985). Le récit et sa construction: Une approche de psychologie cognitive. Neuchâtel: Delachaux-Niestlé.

Fayol, M. (1997). Des idées au texte. Psychologie cognitive de la production verbale, orale et écrite. Paris: Presses Universitaires de France.

Fayol, M. (2017). L'acquisition de l'écrit. Paris : Presses Universitaires de France, Collection: Que sais-je ?

Felouzis, G., \& Perroton, J. (2007). Repenser les effets d'établissement : Marchés scolaires et mobilisation. Revue Française de Pédagogie, 159, 103-118. doi:10.4000/rfp.1133

Fenoglio, I., \& Boucheron-Pétillon, S. (2002). Processus d'écriture et marques linguistiques, Langages, 147.

Fiema, G. (2015). Étude des mouvements de pensée collective lors des ateliers philosophiques au primaire et au collège: extraction de philosophèmes en tant que structures formelles de raisonnement. Thèse de Doctorat. Université Blaise Pascal, Clermont-Ferrand.

Fiema, G., \& Auriac-Slusarczyk, E. (2013). Raisonner en discussion : Illustration sur le sous-corpus Effort, Vie prêtée et Amour. Cahier du LRL, 5, 203-244.

Galbraith D. (1999). Writing as a knowledge constituting process. In G. Rijlaarsdam \& E. Espéret (Series Eds), M. Torrance \& D. Galbraith (Vol. Eds), Studies in writing: Knowing what to write: conceptual processes in text production (pp. 139-160). Amsterdam: Amsterdam University Press. 
Gaonach, D., \& Fijalkov, J. (1998). Notes critiques, débat autour d'un livre: Michel Fayol, Des idées au texte. Psychologie cognitive de la production verbale, orale et écrite. Revue Française de Pédagogie, 125(1), 147-150.

Garcia-Debanc, C. \& Fayol, M. (2002). Des modèles psycholinguistiques du processus rédactionnel pour une didactique de la production écrite, Repères, 26-27, 293-315 ;

García-Moriyón, F., Rebollo, I., \& Colom, R. (2005). Evaluating philosophy for children: A meta-analysis. Thinking: The journal of philosophy for children, 17(4), 14-22. doi: 10.5840/thinking20051743

Gasparatou, R., \& Kampeza, M. (2012). Introducing P4C in kindergarten in Greece. Analytic Teaching and Philosophical Praxis, 33(1), 72-82.

Giménez-Dasí, M., Quintanilla, L., \& Daniel, M.-F. (2013). Improving emotion comprehension and social skills in early childhood through philosophy for children. Childhood and Philosophy, 9(17), 63-89.

Golder, C., (1996). Le développement des discours argumentatifs. Lausanne : Delachaux et Niestlé.

Golder, C., \& Favart, M., (2003). Argumenter c'est difficile... Oui, mais pourquoi ? Approche psycholinguistique de la production argumentative en situation écrite. Etudes de Linguistique Appliquée, 130, 187-209.

Gorard, S., Siddiqui, N., \& See, B. H. (2017). Can 'Philosophy for Children' improve primary school attainment? Journal of Philosophy of Education, 51(1), 5-22. doi:10.1111/1467-9752.12227

Graham, S., McArthur, C.-A., \& Fitzgerald, J. (2007). Best practices in writing instruction. New York, London: The Guilford Press.

Gregory, M. R., Haynes J., \& Murris K. (2017). The routledge international handbook of philosophy for children. London \& New York: Routledge Taylor Francis Group.

Grize, J.-B. (1990). Logique et langage. Paris: Ophrys.

Gunnarson-Largy, C., \& Auriac-Slusarczyk, E. (2013). Ecriture et réécriture chez les élèves. Un seul corpus, divers genres discursifs et méthodologies d'analyse. Paris: Academia-Bruylant.

Haught-Tromp, C. (2017). The green eggs and the ham hypothesis. How constraints facilitate creativity. Psychology of Aesthetics, Creativity, and the Arts, 11(1), 10-17. doi:10.1037/aca0000061 
Hayes J.-R. (1996). A new framework for understanding cognition and affect in writing. In C.M. Levy \& S. Ransdell (Eds), The Science of writing: Theories, methods, individual differences and applications (pp.1-27), Mahwah, NJ, Lawrence Erlbaum Associates.

Hayes, J.-R. (2006). New directions in writing theory. In C.-A. MacArthur, S. Graham \& J. Fitzgerald (Eds.), Handbook of Writing (pp.28-40). New York, London: The Guilford Press.

Hayes J.-R., \& Flower L.S., (1980). Identifying the organization of writing processes. In L.W. Gregg \& E.R. Steinberg, Cognitive processes in writing (pp. 3-30). Hillsdale, N.J : L.E.A.

Heron, G., \& Cassidy, C. (2018). Using practical philosophy to enhance the self-regulation of children in secure accommodation. Emotional and Behavioural Difficulties, 23(3), 254-269. doi:10.1080/13632752.2018.146146

Hofstadter, D., \& Sander, E. (2013). Surfaces and essence. Analogy as the fuel and fire of thinking. New York: Basic Books.

Jenkins, P., \& Lyle, S. (2010). Enacting dialogue: The impact of promoting philosophy for children on the literate thinking of identified poor readers, aged 10. Language and Education, 24(6), 459-472. doi:10.1080/09500782.2010.495781

Lafortune, L., Mongeau, P., Daniel, M. F., \& Pallascio, R. (2000). Approche philosophique des mathématiques et affectivité : Premières mesures. In R. Pallascio \& L. Lafortune (Eds.), Pour une pensée réflexive en éducation (pp. 181-208). Sainte-Foy : Presses de l’Université du Québec.

Leckey, M. (2017). Guernica comes to school. Art, philosophy and life. In M. Gregory, J. Hayes \& K. Murris (Eds.), The routledge international handbook of philosophy for children (pp.137-144). London \& New York : Routledge.

Leleux, C. (2005). La philosophie pour enfants. Le modèle de Matthew Lipman en discussion. Bruxelles: De Boeck \& Larcier.

Lipman, M. (1991/1995). Thinking in education, translation by N. Decostre, À l'école de la pensée. Bruxelles: De Boeck.

Lipman, M., Sharp, A. M., \& Oscanyan, F. S. (1980). Philosophy in the classroom. Philadelphia PA: Temple University Press. 
Lubart, T. I., Besançon, M., \& Barbot, B. (2011). Evaluation du potentiel créatif (EPoC). Paris: Editions Hogrefe.

Maire, H., Auriac-Slusarczyk, E., Slusarczyk, B., Daniel, M. F., \& Thebault, C. (2018). Does one stand to gain by combining Art with Philosophy? A study of fourth-year college (13/14 years of age) philosophical writings produced within the PreCPhi/Philosophemes Corpus. Journal of Education and Learning, 7(4). doi:10.5539/jel.v7n4p1

McArthur, C.-A., Graham, S., \& Fitzgerald, J., (2006). Handbook of writing. New York, London: The Guilford Press.

Millett, S., \& Tapper, A. (2012). Benefits of collaborative philosophical inquiry in schools. Educational Philosophy and Theory, 44(5), 546-567. doi:10.1111/j.1469-5812.2010.00727.x

Mortier, F. (2005). Etude d'évaluation : la méthode de Matthew Lipman comme moyen de développement. In C. Leleux (Ed.), La philosophie pour enfants. Le modèle de Matthew Lipman en discussion (pp. 47-69). Bruxelles: De Boeck \& Larcier.

Newell, G.E., Koukis, S., \& Boster, S. (2007). Best practices in developing a writing cross the curriculum program in the secondary school. In S. Graham, C.-A. McArthur, \& J. Fitzgerald (Eds.), Best practices in writing instruction (pp.74-98). New Yok, London: The Guilford Press.

Pallascio, R., \& Lafortune, L. (2002). Pour une pensée réflexive en éducation. Québec: Presses Universitaire du Québec.

Piolat, A. (2010). Approche cognitive de la prise de notes comme écriture de l'urgence et de la mémoire externe. Le français aujourd'hui, 3(170), 51-62.

Piolat, A., \& Barbier, M.-L., (2007). De l'écriture elliptique estudiantine : Analyse descriptive de prises de notes et de brouillons. Langue Française, 155, 84-100.

Pouit, D., \& Golder, C. (1996). Peut-on faciliter l'argumentation écrite ? Effets d'un schéma de texte, d'une liste d'idées et d'un thème familier. Archives de Psychologie, 64, 179-199.

Pouit, D., \& Golder, C., (1997). Il ne suffit pas d'avoir des idées pour défendre un point de vue. La récupération des idées peut-elle faciliter la production écrite d'une argumentation chez les enfants de 11 à 17 ans ? Revue de Psychologie de l'Education, 3, 33-52. 
Rey, V., Romain, C., \& Demartino, S. (2015). La fonction patrimoniale du langage: une remédiation des troubles langagiers chez des adolescents autistes sans déficit intellectuel. Les Cahiers de Santé Publique et de Protection Sociale, 17, 17-22.

Rijlaarsdam, G., Van den Berg, H., \& Couzijn, M., (2005). Effective learning and teaching of writing. New York: Kluver Academic Publishers.

Rispail, M. (2007). Apprendre à parler, apprendre à penser. Les ateliers de philosophie. Paris: Scéren.

Saint-Dizier de Almeida, V., Colletta, J.-M., Auriac-Slusarczyk, E., Specogna, A., \& Fiema, G. (2016). Collaborative philosophical inquiry: A theoretical and methodological framework applied to a case study. International Journal of Qualitative Studies in Education, 29(5), 686-713. doi:10.1080/09518398.2016.1145277

Säre, E., Luik, P., \& Tulviste, T. (2016). Improving pre-schoolers' reasoning skills using the philosophy for children programme. Trames: Journal of the Humanities and Social Sciences, 20(3), 273-295. doi:10.3176/tr.2016.3.03

Sanders, T. J.-M., \& Schildperoord, J. (2006). Text structure as a window on the cognition of writing. In C.-A. McArthur, S. Graham, \& J. Fitzgerald (Eds.), Handbook of Writing (pp. 386-402). New York, London: The Guilford Press.

Scardamalia, M., \& Bereiter, C. (1991). Literate expertise. In K.A. Ericsson \& J. Smith (Eds.), Toward a general theory of expertise (pp. 172-194). Cambridge: University Press.

Siddiqui, N., Gorard, S., \& See, B. H. (2017). Non-cognitive impacts of philosophy for children (pp. 1-49). School of Education: Durham University.

Slusarczyk, B. (2010). Approcher la qualité textuelle des écrits scolaires : le corpus grenouille à l'essai d'un jugement d'expert. Synergies Pays Scandinaves, 5, 97-110.

Slusarczyk, B. (2017). Philosoph'arts. Cartographie philosophique à l'usage de collégiens. Clermont Ferrand: Édition Un deux quatre.

Slusarczyk, B., Fiema, G., Auriel, A., \& Auriac-Slusarczyk, E. (2015). Étude de l'impact d'une introduction de la philosophie dans les curriculums au primaire et au collège sur l'intégrité cognitive. Recherche et Education, 14, 123-145. 
Sternberg, R. J., \& Lubart, T. I. (1995). Defying the crowd: Cultivating creativity in a culture of conformity. New York: Free Press.

Talbot, G. (1999). Phil et Sophie ou de l'Etre Humain. Québec: Le loup de Gouttière.

Tian, S., \& Liao, P. F. (2016). Philosophy for children with learners of English as a foreign language. Journal of Philosophy in Schools 3(1), 40-58.

Topping K. J., \& Trickey, S. (2007a). Collaborative philosophical enquiry for school children: Cognitive gains at two-year follow-up. British Journal of Educational Psychology, 77(4), 787-796. doi:10.1348/000709906X105328

Topping, K. J., \& Trickey, S. (2007b). Impact of philosophical enquiry on school students' interactive behaviour. Thinking Skills and Creativity, 2(2), 73-84.doi:10.1016/j.tsc.2007.03.001

Topping, K. J., \& Trickey, S. (2014). The role of dialog in philosophy for children. International Journal of Educational Research, 63, 69-78. doi:10.1016/j.ijer.2013.01.002

Torrance, M. \& Jeffery, G (1999, Eds). The cognitive demands of writing. Amsterdam: Amsterdam University Press.

Torrance, M., Thomas G. V., \& Robinson E.J. (1996). Finding something to write about: strategic and automatic processes in idea generation. In C.M. Levy \& S. Ransdell (Eds.). The Science of writing: Theories, methods, individual differences and applications (pp.199-205), Mahwah, NJ, Lawrence Erlbaum Associates.

Tozzi, M. (2007). Apprendre à philosopher par la discussion: pourquoi? comment? Bruxelles: De Boeck.

Trickey, S., \& Topping K. J. (2004) Philosophy for Children: A systematic review. Research Papers in Education, 19(3), 365-380. doi:10.1080/0267152042000248016

Trickey, S., \& Topping, K. J. (2006). Collaborative philosophical enquiry for school children: Socioemotional effects at 10-12 years. School Psychology International, 27(5), 599-614. doi:10.1177/0143034306073417

Villalba, E. (2008). On Creativity. Towards an Understanding of Creativity and its Measurements, JRC Scientific and Technological Reports, CRELL, EUR 23561. Luxembourg: Publications of the European Communities. 
Vygotski, L. S. (1962). Thought and language. Cambridge, MA: The Massachusetts Institute of Technology Press.

Walker, C. M., Wartenberg, T. E., \& Winner, E. (2013). Engagement in philosophical dialogue facilitates children's reasoning about subjectivity. Developmental Psychology, 49(7), 1338-1347. doi:10.1037/a0029870

Yusoff, W. M. W. (2018). The impact of Philosophical Inquiry Method on classroom engagement and reasoning skills of low achievers. Journal of Curriculum and Teaching, 7(1), 135-146. doi:10.5430/jct.v7n1p135 